\title{
Survey and Symptomatology of Grapes Downy Mildew Pathogen (Plasmopara viticola)
}

\author{
P. Valarmathi ${ }^{1 *}$ and D. Ladhalakshmi ${ }^{2}$ \\ ${ }^{1}$ ICAR-Central Institute for Cotton Research (CICR), Coimbatore-641 003, India \\ ${ }^{2}$ Department of Plant Pathology, ICAR-Indian Institute of Rice Research (IIRR), \\ Hyderabad-500 030, India \\ *Corresponding author
}

\section{A B S T R A C T}

\begin{tabular}{|l|} 
Ke y w o r d s \\
Grapes, \\
$\begin{array}{l}\text { Plasmopara } \\
\text { viticola, } \\
\text { Symptomatology }\end{array}$ \\
\hline Article Info \\
\hline $\begin{array}{l}\text { Accepted: } \\
\text { 14 June } 2020 \\
\text { Available Online: } \\
\text { 10 July } 2020\end{array}$ \\
\hline
\end{tabular}

Survey was conducted during 2013-2014 (August 2013-February 2014) in the grapes growing areas of Tamil Nadu viz., Coimbatore, Dindigul and Theni districts to assess the disease incidence of downy mildew. Accordingly, the per cent incidence ranged between 30.74 and 78.17 in all the districts surveyed. Among the different districts surveyed, maximum incidence of downy mildew was recorded in Cumbum area of Theni (78.17 per cent) during inflorescence stage and the lowest incidence of 30.74 per cent was observed in the village Uthupatty of Dindugal district during fruiting stage. Among the area surveyed in Coimbatore district, Mathampatty recorded maximum incidence of 72.55 per cent at 35-45 days after pruning.

\section{Introduction}

Grapes is the most important temperate fruit crop that has successfully adapted to the subtropical and tropical agro-climatic conditions. Grapevine, a highly remunerative fruit crop in India, is vulnerable to many fungal diseases viz., downy mildew, powdery mildew and anthracnose (Vyas, 1993). These diseases affect the foliage, tender shoots, inflorescence and berries resulting in considerable loss in yield as well as quality of fruits. However, the grapevine is susceptible to many fungal diseases, specially the downy mildew results into economic losses to the tune of $50-100 \%$.

Downy mildew of grapevine is indigenous to Eastern North American where it spread from wild grapes to cultivated vineyards (Winkler et al., 1974; Viennot-Bourgin, 1981). In India the disease was first reported by Syndow and Butler, 1912 from Pune, Maharashtra. Subsequently the incidence of downy mildew was reported from different places in India. In Tamil Nadu, first time Ramakrishnan and Sundaram, 1955 reported the occurrence of 
this disease. Leaves, tendrils, shoot, inflorescences and clusters are affected by downy mildew disease (Anderson, H. W., 1956). The symptomatology of downy mildew on grapevine was well documented. The first symptom of disease appeared on the new flush as small light green patches on the upper surface of the leaves and a whitish downy growth on the corresponding lower surface. The downy growth of fungus spread rapidly on the lower surface which turned corresponding greenish patches on upper surface in yellow and chlorotic (oil spots) with age (Winkler et al., 1974). The mildew growth covered the entire leaf blade which turned brown and withered. Severely infected leaves may curl and drop from the vine. The disease attacks older leaves in late summer and autumn producing a mosaic of small, angular, yellow to red- brown spots on the upper leaf surface (Schwarz et al., 1984).

The infections of the shoots caused water soaked lesions on which downy growth of the fungus appeared in the course of the next few days. When young shoots, petioles, tendrils or cluster stems are infected, they frequently become distorted, thickened or curled. Infected flowers died and dropped off (Srinivasan and Jeyarajan, 1976). The fruits became greyish; the skin hardened and shriveled. They were mummified remaining attached to bunch. Infected berries are easily detached from their pedicels leaving a dry stem scar. Infected green fruit turn light brown to purple, shrivel and detach easily. White cottony sporulation was abundant on these berries during humid weather (Srinivasan and Jeyarajan, 1977a and 1977 b). Lafon and Bulit, 1981 reported that symptoms of downy mildew disease on leaves varied according to leaf age and prevailing weather condition and the nodes were more susceptible than the internodes. Srinivasan and Jeyarajan, 1983 found that inflorescence and young developing bunches were more susceptible than mature berries. Ramarethinam et al., 2001 observed that the development of oil spot was quick in warm weather $\left(20-25^{\circ} \mathrm{C}\right)$ and the downy mildew epidemics often began in more humid sheltered or low lying areas of vineyards.

\section{Materials and Methods}

Survey to record the occurrence of downy mildew caused by Plasmopara viticola in major grapes growing areas of Tamil Nadu

Survey was conducted during 2013-2014 (August 2013-February 2014) in some of the grapes growing areas of Tamil Nadu viz., Coimbatore, Dindigul and Theni districts to assess the disease incidence of downy mildew.

\section{Disease score chart}

The incidence of downy mildew was assessed using the standard score chart given by Jamadar and Desai (1997).

\section{Leaf}

\begin{tabular}{|c|c|}
\hline Disease grade & Per cent leaf area affected \\
\hline 0 & No infection \\
\hline 1 & 0 to 10 \\
\hline 3 & $>10$ to 15 \\
\hline 5 & $>15$ to 25 \\
\hline 7 & $>25$ to 50 \\
\hline 9 & $>50$ \\
\hline
\end{tabular}

The per cent disease index was calculated using Mc Kinney's (1923) formula

$\mathrm{PDI}=$

\begin{tabular}{cc} 
Sum of all numerical ratings & 100 \\
\hline Total number of leaves observed & Maximum grade in the score chart
\end{tabular}




\section{Inflorescence}

The incidence of downy was observed at randomly in 15 inflorescence per plot leaving the border rows. Based on the score chart given by Jamadar and Desai (1997), the per cent disease index was calculated.

\begin{tabular}{|c|c|}
\hline Disease grade & $\begin{array}{c}\text { Per cent infection in } \\
\text { inflorescence }\end{array}$ \\
\hline 0 & No infection \\
\hline 1 & 0 to 10 \\
\hline 2 & $>10$ to 15 \\
\hline 3 & $>15$ to 25 \\
\hline 4 & $>20$ to 50 \\
\hline 5 & $>50$ \\
\hline
\end{tabular}

\section{Fruit}

The disease incidence was recorded in 15 fruit bunches per plot by adopting the scale given by Rao (1991) where,

\begin{tabular}{|c|c|}
\hline Disease grade & Per cent infection in fruit \\
\hline 0 & No infection \\
\hline 1 & Traces of infection \\
\hline 2 & 25 to 50 \\
\hline 3 & $>50$ to 75 \\
\hline 4 & $>75$ to 100 \\
\hline
\end{tabular}

\section{Results and Discussion}

A survey was conducted during August, 2013 - February, 2014 in major grapes growing areas of Tamil Nadu viz., Coimbatore, Dindigul and Theni to record the incidence of downy mildew. Accordingly, the per cent incidence ranged between 30.74 and 78.17 in all the districts surveyed. Among the different districts surveyed, maximum incidence of downy mildew was recorded in Cumbum area of Theni (78.17 per cent) during inflorescence stage and the lowest incidence of 30.74 per cent was observed in the village Uthupatty of Dindugal district during fruiting stage. Among the area surveyed in Coimbatore district, Mathampatty recorded maximum incidence of 72.55 per cent at 35-45 days after pruning (Table 1).

Table.1 Incidence of downy mildew in major grapes growing areas of Tamil Nadu

\begin{tabular}{|c|l|l|c|}
\hline S. No. & \multicolumn{1}{|c|}{ Name of the District } & \multicolumn{1}{|c|}{ Name of the village } & *Per cent incidence \\
\hline $\mathbf{1 .}$ & Coimbatore & Thondamuthur & $\mathbf{7 1 . 3 3}$ \\
\hline $\mathbf{2 .}$ & Coimbatore & Mathampatty & $\mathbf{7 2 . 5 5}$ \\
\hline $\mathbf{3 .}$ & Coimbatore & Mathipalayam & $\mathbf{6 8 . 2 5}$ \\
\hline $\mathbf{4 .}$ & Coimbatore & Coimbatore & $\mathbf{7 0 . 3 7}$ \\
\hline $\mathbf{5 .}$ & Dindigul & Chakkainayakanur & $\mathbf{3 7 . 7 5}$ \\
\hline $\mathbf{6 .}$ & Dindigul & Chinnalapatty & $\mathbf{4 2 . 7 5}$ \\
\hline $\mathbf{7 .}$ & Dindigul & Kamalapuram & $\mathbf{7 0 . 3 7}$ \\
\hline $\mathbf{8 .}$ & Dindigul & Uthupatty & $\mathbf{3 0 . 7 4}$ \\
\hline $\mathbf{9 .}$ & Theni & Cumbum & $\mathbf{7 8 . 1 7}$ \\
\hline $\mathbf{1 0 .}$ & Theni & Surulipatty & $\mathbf{7 3 . 7 5}$ \\
\hline
\end{tabular}

* Mean of four replications 

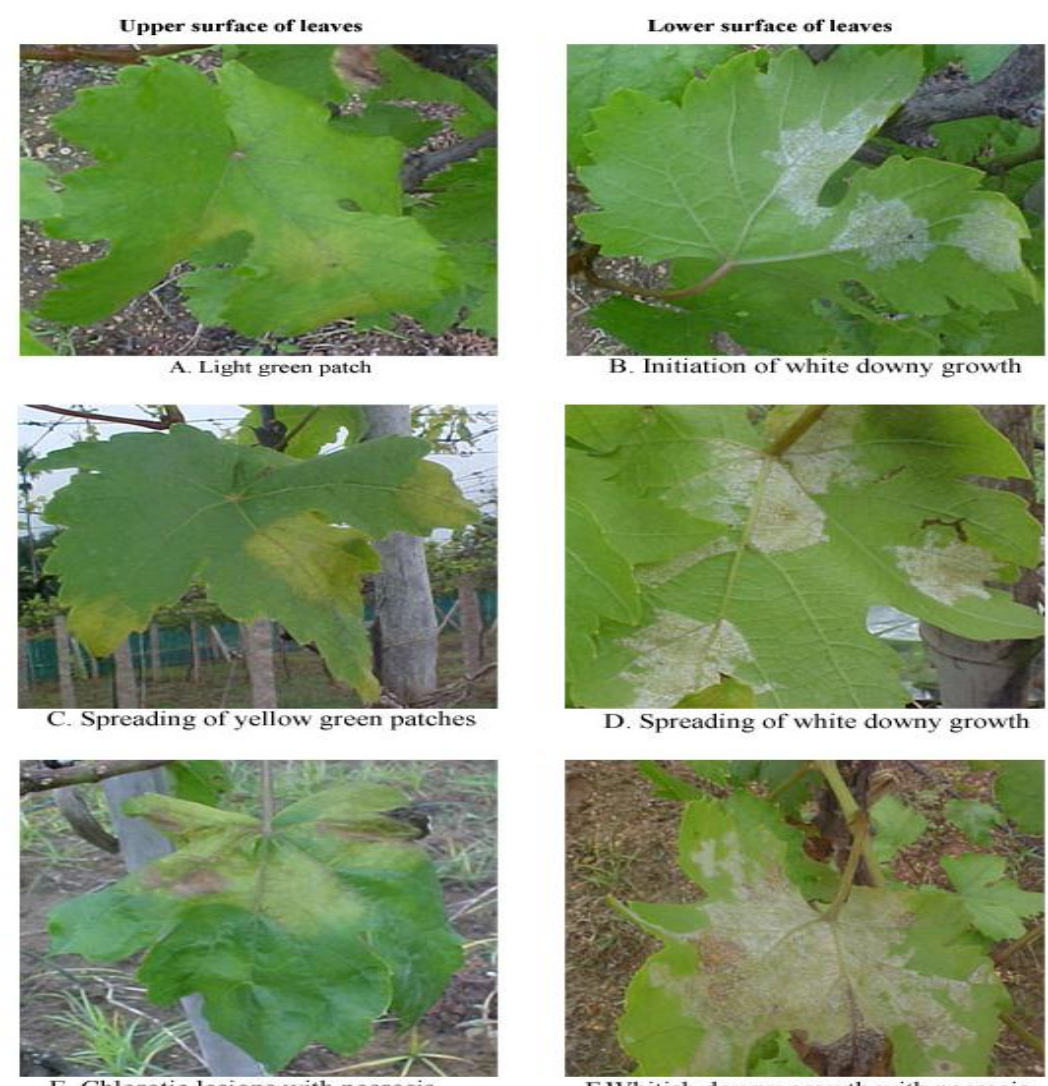

E. Chlorotic lesions with necrosis



Plate.1 Symptoms of grapes downy mildew
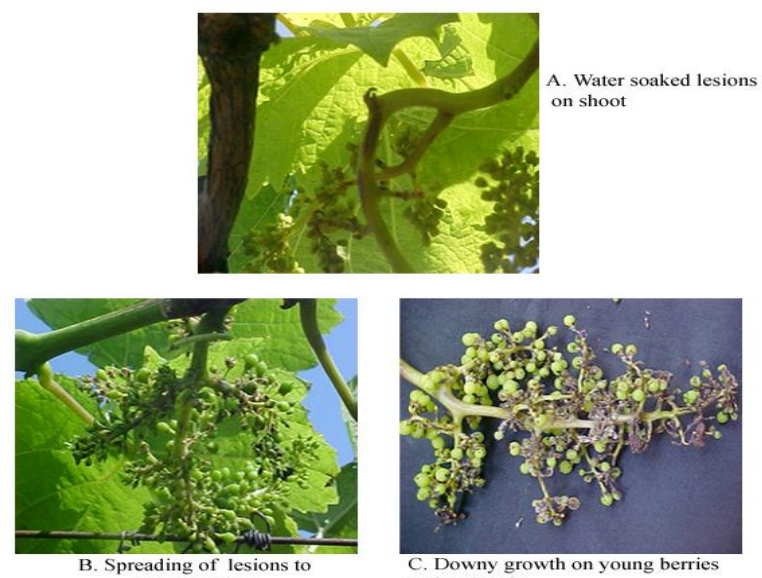

B. Spreading of lesi
inflorescence
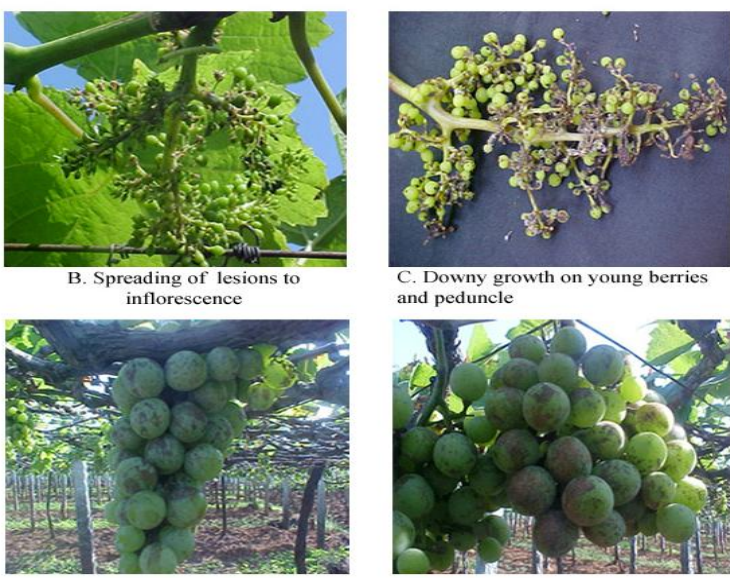
and peduncle

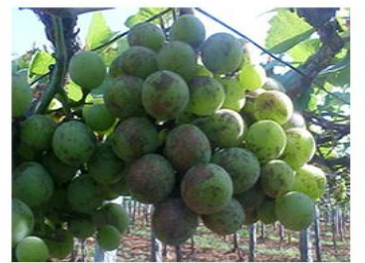

D \& E. Infected fruit bunch with mummified fruits

Plate.2 Symptoms of grapes downy mildew on inflorescence and fruits 


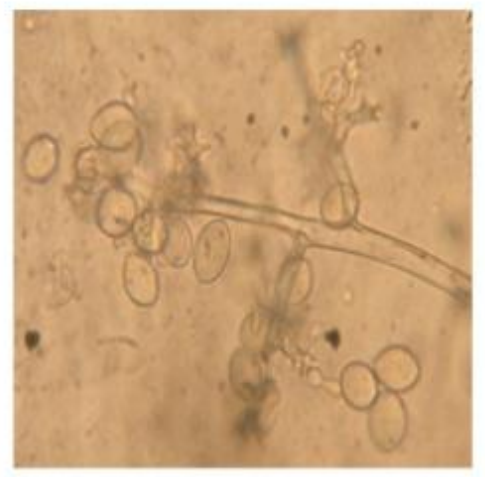

A. Sporangia with sporangiophore



B. Acute right angled sporangiophore

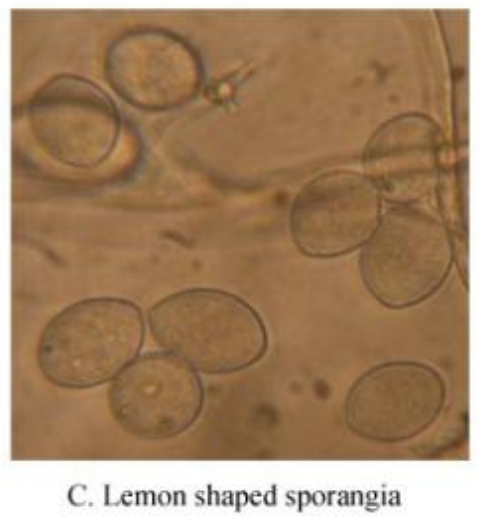

Plate.3 Morphological characters of $P$. viticola

The Symptomatology of downy mildew on grapevine was well documented. The first symptom of the disease appeared on the new flush as small light green patches on the upper surface of the leaves and a white downy mildew growth on the lower surface (Plate 1A and $\mathrm{B}$ ). The fungus spread rapidly with profuse downy growth on the lower surface with corresponding greenish patches on the upper surface which turned yellow and chlorotic (oil spots) with age (Plate $1 \mathrm{C}, \mathrm{D}$ and $\mathrm{E}$ ). The mildew growth covered the entire leaf blade that turned brown and withered (Plate 1F). The infection of the shoots caused water soaked lesions initially then downy growth of the fungus was observed (Plate $2 \mathrm{~A}$, $\mathrm{B}$ and $\mathrm{C}$ ). Infected flowers dried and dropped off and the fruits became grayish with hardened and shriveled skin and became mummified remaining attached to the bunch (Plate $2 \mathrm{D}$ and $\mathrm{E}$ ). The fungus produces large number of asexual sporangia which are hyaline, ellipsoidal and papillate. They are produced at the tips of acutely right angled branched sporangiosphores that usually arise from mycelial cushions in the substomatal cavity (Plate $3 \mathrm{~A}$ to $\mathrm{C}$ ).

In the present study, the symptom of grapes downy mildew has been documented. Initially small light green patches appear on the upper surface and a white downy mildew growth on the lower surface of leaves of the new flush. The mildew growth covered the entire leaf blade that turned brown and withered. These symptoms show corroboration with reports on grapevine by earlier researchers (Winkler et al., 1974; Schwarz et al., 1984; 
Ramarethinam et al., 2001). The infection of the shoots caused water soaked lesions on which downy growth of the fungus appeared in the course of next few days as mentioned by Srinivasan and Jeyarajan, 1976. Infected flowers dried and dropped off and the fruits became grayish with hardened and shriveled skin and became mummified remaining attached to the bunch (Srinivasan and Jeyarajan, 1977a and 1977 b).

\section{References}

Anderson, H.W. 1956. Diseases of grapes. In: Diseases of fruit crops. Mc Graw-Hill, New York. pp 364-382.

Jamadar, M.M. and Desai, S. A. 1997. Bioefficacy of dimethomorph against downy mildew of grapevine. $A d v$. Agric. Res. India. 4: 81-85.

Lafon, R. and J. Bulit, J. 1981. Downy mildew of vine. In: The Downy mildew. (Eds) Spencer, D. M., Academic Press, London, pp. 601-614.

Mc Kinney, H. H. 1923. A new system of grading of plant diseases. J. Agric. Res., 26: 195-218.

Ramakrishnan, T.S. and Sundaram. N.V. 1955. Grapevine diseases and their control. Madras Agric. J., 42: 109-113.

Ramarethinam, S., Murugesan, N.V. and Latha, P. 2001. Bio-ecology of Plasmopara viticola causing downy mildew in grapes and its control. Pestology, 25(15): 2-6.

Rao, K.C. 1991. Management of grapevine powdery mildew with sterol inhibiting fungicides. Pestology, 15: 43-45

Schwarz, M. R., Pearson, R. C., Burr, T. J., Seem, R. C. and McMillen-Sticht, R.
1984. Grape IPM, Disease Identification Sheet No. 5. Published by the New York State Agricultural Experiment Station, Geneva.

Srinivasan, N. and Jeyarajan, R. 1976. Grapevine downy mildew in India I. Foliar, floral and fruit infections. Vitis, 15: 113-120.

Srinivasan, N. and Jeyarajan, R. 1977a. Grapevine downy mildew in India III. Effect of infection on phenolics, sap concentration and amino acids. Madras Agric. J., 64: 797-802.

Srinivasan, N. and Jeyarajan, R. 1977b. Grape downy mildew in India. Effect of infection on sugar content and respiration in leaves. Indian J. Hort., 34: 209-214.

Srinivasan, N. and Jeyarajan, R. 1983. Influence of positions in grapevine flowers and berries on downy mildew (Plasmopara viticola). Madras Agric. J., 70: 57-58.

Syndow, H. and Butler, E. J. 1912. Fungi India Orientasles pars. Ann. Mycol., 9: 372-421

Viennot-Bourgin, G. 1981. History and importance of downy mildew. In: Downy mildews (ed.) Spencer, D.M., Academic press, London, pp 1-15

Vyas, S. C. 1993. Triazoles - Hand book of Systemic fungicides- Compounds Volume II, Tata McGraw- Hill Publishing Company Limited, New Delhi, India. pp. 349-401.

Winkler, A. J., Cook, J. A., Kliewar, W. M. and Lider, L. A. 1974. General viticulture. University of California Press, Berkeley, p. 446.

\section{How to cite this article:}

Valarmathi, P. and Ladhalakshmi, D. 2020. Survey and Symptomatology of Grapes Downy Mildew Pathogen (Plasmopara viticola). Int.J.Curr.Microbiol.App.Sci. 9(07): 1688-1693. doi: https://doi.org/10.20546/ijcmas.2020.907.194 